\title{
GENOTOXIC AND ANTIGENOTOXIC POTENTIAL OF THE LAGENANDRA TOXICARIA DALZ. RHIZOME METHANOL EXTRACT USING ALLIUM CEPA ASSAY
}

\author{
AKARSHA B, KRISHNAKUMAR G* \\ Department of Applied Botany, Mangalore University, Mangaluru, Karnataka, India. Email: Kkgtaxo13@gmail.com
}

Received: 20 February 2021, Revised and Accepted: 30 March 2021

\begin{abstract}
Objective: The study is to evaluate the possible genotoxic and antigenotoxic potential of Lagenandra toxicaria rhizome methanol extract using Allium cepa root tip assay.

Methods: The rhizome methanol extract was prepared using Soxhlet apparatus. The A. cepa roots were treated with various concentrations of the extract at different time points and stained with aceto-orcein. The mitotic index (MI) was calculated.

Results: A significant decrease in MI and increase in the percentage of clastogenicity was observed in a time- and dose-dependent manner in the roots treated with the extract at $0.2 \mathrm{mg} / \mathrm{ml}, 0.5 \mathrm{mg} / \mathrm{ml}, 1 \mathrm{mg} / \mathrm{ml}, 5 \mathrm{mg} / \mathrm{ml}$, and $10 \mathrm{mg} / \mathrm{ml}$ concentration for 1,2 , and $4 \mathrm{~h}$. The field emission scanning electron microscopy and Fourier-transform infrared spectroscopy revealed evident morphological and biochemical changes at 10 mg/ml treatment when compared to control for $4 \mathrm{~h}$. The agarose gel electrophoresis showed loss of DNA integrity at $10 \mathrm{mg} / \mathrm{ml}$ extract for $4 \mathrm{~h}$. In situ histochemical staining by Schiff's reagent and nitroblue tetrazolium confirmed the increased lipid peroxidation and free radical generation at $4 \mathrm{~h}$ treatment. Subsequently, the possible antigenotoxic potential of the plant extract was explored using $\mathrm{H}_{2} \mathrm{O}_{2}$ standard assays. The increased percentage of $\mathrm{H}_{2} \mathrm{O}_{2}$ induced nuclear lesions was reduced significantly after the modulatory treatment with extract.
\end{abstract}

Conclusion: The L. toxicaria rhizome methanol extract acts as an antigenotoxic agent at lower doses and at higher doses the extract induces clastogenic effects. Further studies are needed to unravel the active component in the extract that mediates the observed phenomenon in the current study.

Keywords: Lagenandra toxicaria, Allium cepa assay, Genotoxicity, Antigenotoxicity, DNA integrity.

(C) 2021 The Authors. Published by Innovare Academic Sciences Pvt Ltd. This is an open access article under the CC BY license (http://creativecommons.org/ licenses/by/4.0/) DOI: http://dx.doi.org/10.22159/ajpcr.2021v14i5.41174. Journal homepage: https://innovareacademics.in/journals/index.php/ajpcr

\section{INTRODUCTION}

Plants are the major source of traditional medicine, practiced since prehistoric times. Each plant has its own chemical constituents and secondary metabolites. In Ayurveda, more than 700 plant-based medicines were discussed for promoting healthy life [1]. Traditional healers use numerous plant based remedies to treat various diseases, of which very few have been scientifically established for their mode of action. The plant-based therapeutic modalities are safer and cost effective than the synthetic drugs. The plant of interest in the present study, Lagenandra toxicaria is an herb of the family Araceae. It is endemic to southern India and commonly seen in marshy regions. The rhizome of the plant is used in the traditional system to treat bilious complaints and also in renal and cardiac ailments. The plant is recognized to be diuretic, carminative and used as tonic [2]. The major storage protein in the members of Araceae is lectin [3] which is used in the development of anticancer therapeutics as it can bind to the cancer cell membranes and/or receptors causing the cell to undergo apoptosis [4]. The rhizome oil is known for its insecticidal activity and the plant juice enhances wound healing. The antibacterial activities of the plant against human pathogens have also been explored $[5,6]$.

With these wide ranging therapeutic applications, it becomes imperative to ensure that the plant extract is nontoxic and safe. Genotoxicity of plant products is an area of concern since it can covertly damage the genetic makeup. Genotoxic materials are also of interest since they can be potential candidates as therapies for disease like cancer.

The present study is to evaluate the genotoxic and antigenotoxic potential of L. toxicaria using Allium cepa root tip assay. This assay is less expensive, sensitive, and a widely used study model. The larger chromosome of A. сера which are easily observable under light microscope is an added advantage of this model. Earlier studies report that the effects of genotoxic agents on A. cepa cells and animal cells are similar and comparable [7,8]. The genotoxic and anti-genotoxic effects of the plant extract have been evaluated at different doses and different time intervals to establish whether the effect is time- and dose-dependent. It also enables us to explore the mechanisms through which the extract is acting on the root tips. Induction of oxidative stress is one of the common ways by which a compound causes DNA damage and chromosomal aberrations leading to cellular damage and apoptosis $[9,10]$.

\section{METHODS}

\section{Reagents}

DNA isolation kit was obtained from HiMedia Ltd. Mumbai, India. Schiff's, Triphenyl tetrazolium chloride (TTC), Nitroblueterasolium (NBT), FC reagent, $\mathrm{Na}_{2} \mathrm{CO}_{3}, \mathrm{H}_{2} \mathrm{O}_{2}$, and Galic acid reagents were obtained from Nice Pvt Ltd. Kerala. Other chemicals used were all of analytical grade.

\section{Plant collection and extraction}

The $L$. toxicaria rhizomes were collected from the markanja village of Sullia taluk, Dakshina Kannada District, Karnataka, India (12³4'38.7”N, $\left.75^{\circ} 29^{\prime} 54.8^{\prime \prime} \mathrm{E}\right)$. The plant was identified taxonomically and herbarium (AK 08) was deposited in the Department of Applied Botany Mangalore University. The rhizomes were cleaned, washed under running tap water, chopped into small pieces, and dried in shade. Dried samples were finely powdered using lab mill. The powdered samples were subjected to methanol extraction in a Soxhlet apparatus at $60^{\circ} \mathrm{C}[11]$. The obtained extracts were concentrated in rotary evaporator and dried in lyophilizer. The extract stock solution of $1 \mathrm{mg} / \mathrm{ml}$ and $10 \mathrm{mg} / \mathrm{ml}$ was prepared in 1\% DMSO and used for further analysis. 


\section{Genotoxicity test}

Healthy onion bulbs were collected. The outer old scales were peeled and the old roots were scraped off. These bulbs were placed on a coupling jar containing double distilled water and kept in dark for 3-4 days to allow the growth of fresh roots. The onion bulbs $(n=6)$ with well-developed roots were picked at their peak mitotic period and were treated with extracts at concentrations $(0.2,0.5,1,5$, and $10 \mathrm{mg} / \mathrm{ml}$ in $1 \%$ DMSO $)$ for 1,2 , and $4 \mathrm{~h}$. The $1 \%$ DMSO and water were used as controls, and the $3 \% \mathrm{H}_{2} \mathrm{O}_{2}$ served as the positive control for genotoxicity $[12,13]$. After the treatment, root tips of each treatment were excised, washed with distilled water and transferred to a cool mixture $\left(4-10^{\circ} \mathrm{C}\right)$ of ethanol and glacial acetic acid (3:1) fixative and incubated for $1 \mathrm{~h}$. These root tips were hydrolyzed with the $1 \mathrm{~N} \mathrm{HCl}$ for about $15 \mathrm{~min}$ at $55-60^{\circ} \mathrm{C}$, then stained with aceto-orcein for 5-10 min and placed on a microscope slide, root tip region was isolated ( $M$ region), covered with a coverslip, squashed and observed under $\times 40$ objective lens of the (Olympus CH20i) microscope [14,15].

The cells were observed for mitotic aberrations in the randomly selected microscopic fields. About 700-800 cells were counted for each treatment and the MI and the cellular aberrations were examined.

The mitotic index (MI) was calculated using the formula:

$$
\frac{\text { Number of dividing cells }}{\text { Total number of observed cells }} \times 100
$$

The percentage of chromosomal aberration was determined as the ratio of the number of aberrant cells to the total number of observed cells, that is,

$$
\frac{\text { Number of aberrant cells }}{\text { Total number of observed cells }}
$$

\section{Testing of DNA damage}

The DNA was isolated from the treated root tip samples using HiMedia plant genomic DNA Miniprep kit MB507-20PR, following the manufacturer's instructions. The isolated DNA samples were loaded into $2 \%$ agarose gel and subjected to electrophoretic separation at $50 \mathrm{~V}$ and visualized by ethidium bromide staining. The gel pictures were documented using the UVCI-1100 ms major science system, Major science manufacturer, 19959 Sea Gull Way, Saratoga, U.S.A [16-18].

\section{Quantitative analysis of total polyphenol content and flavonoids}

The quantitative estimation of the polyphenols $(n=3)$ was done using FC reagent spectrometric method [19]. Gallic acid was taken as the standard. Absorbance was measured at $735 \mathrm{~nm}$. Total flavonoid content $(n=3)$ was estimated using aluminum chloride spectrometric method [20]. Quercetin was taken as the standard and absorbance was measured at $415 \mathrm{~nm}$.

\section{Examination of in situ lipid peroxidation}

After the treatment $(n=6)$ with various concentration of the extract $(0.2,0.5,1,5$, and $10 \mathrm{mg} / \mathrm{ml}), 1 \%$ DMSO and $3 \% \mathrm{H}_{2} \mathrm{O}_{2}$, the roots were incubated in Schiff's reagent for $2 \mathrm{~h}$. Then, the roots were washed with $0.5 \%(\mathrm{w} / \mathrm{v}) \mathrm{K}_{2} \mathrm{~S}_{2} \mathrm{O}_{5}$ (prepared in $0.05 \mathrm{M} \mathrm{HCl}$ ) solution for $20 \mathrm{~min}$, leading to the visualization of the Malondialdehyde which is a possible product of the lipid peroxidation $[13,21]$.

\section{Viability test using TTC}

The cell viability of the extract treated roots $(n=6)$ was assessed using the $0.5 \%$ of $2,3,5$ TTC in phosphate buffer following the procedure of Shaymurat et al. (2012) [22]. The images were captured using canon power shot SX400 IS camera.

\section{Measurement of superoxide anion radical $\left(O^{\circ}\right)$}

Measurement of superoxide anion radical was carried out for the root tip $(n=6)$ treated with $0.2,0.5,1,5$, and $10 \mathrm{mg} / \mathrm{ml}$ of the extract for
$4 \mathrm{~h}$. About 1\% DMSO served as a negative control and $3 \% \mathrm{H}_{2} \mathrm{O}_{2}$ was the positive control. The treated roots were kept in $0.1 \%$ nitroblue tetrazolium (in $50 \mathrm{Mm}$ phosphate buffer ph 7.4) and placed under light until the blue colored farmazone precipitate appears. The roots were then washed with 95\% alcohol $[23,24]$.

\section{Fourier-transform infrared spectroscopy (FTIR) analysis of treated root tips}

From the onion root tips $(n=6)$ subjected to various treatments, root tips of each treatment were dried in an oven for $15 \mathrm{~h}$ at $60^{\circ} \mathrm{C}$ and the dried samples were finely powdered. The powder was analyzed by FTIR to know the possible differences in the characteristic signal of the biochemical components of the different root samples $[13,25]$.

\section{Root ultrastructure studies using field emission scanning electron} microscopy

The root tips treated with $1 \%$ DMSO (control) and different concentrations of methanol extracts such as $1 \mathrm{mg} / \mathrm{ml}, 5 \mathrm{mg} / \mathrm{ml}$, and $10 \mathrm{mg} / \mathrm{ml}$ were excised washed with PBS and then fixed in $2.5 \%$ glutaraldehyde and $2 \%$ paraformaldehyde in $0.1 \mathrm{M}$ sodium phosphate buffer (pH 7.2) for $12 \mathrm{~h}$ at $4^{\circ} \mathrm{C}$ with intermittent stirring. Roots were dehydrated using ethanol series $(10 \%, 20 \%, 30 \%, 50 \%$, and $70 \%)$. Dehydrated roots were gold sputter coated and observed under FSESM at $5 \mathrm{KV}$ voltage following the procedure of Ahmed et al. (2017) [26], Shahid, et al. (2018) [27], and Shetty et al. (2017) [13]

\section{Examination of antigenotoxicity activity of $L$. toxicaria methanol extract}

The onion roots were grown as mentioned previously. The healthy bulbs $(n=6)$ with sufficient number of roots were treated with the $3 \% \mathrm{H}_{2} \mathrm{O}_{2}$ for $1 \mathrm{~h}$. Then, the roots were incubated with different concentrations of the plant extract $(0.04,0.02,0.01,0.005$, and $0.0025 \mathrm{mg} / \mathrm{ml})$ for $24 \mathrm{~h}$ to analyze the possible antigenotoxic potential of the extract. The roots treated with the $3 \% \mathrm{H}_{2} \mathrm{O}_{2}$ served as the control. The squash was made and observed under the microscope as mentioned previously.

The antigenotoxicity potency of the plant extract was calculated using the following formula

Inhibitory activity $(\%)=\mathrm{A}-\mathrm{B} / \mathrm{A}-\mathrm{C} \times 100$

$A=$ Number of aberrant cells induced by hydrogen peroxide

$B=$ Number of aberrant cells observed after treating hydrogen peroxide treated roots with plant extract

C=Number of aberrant cells observed in 1\% DMSO control group

The group treated with one percent DMSO was taken as a negative control. The group treated with $3 \% \mathrm{H}_{2} \mathrm{O}_{2}$ and $1 \%$ DMSO was considered as a positive control. The lipid peroxidation of the treated root was evaluated using Schiff's reagent.

\section{Statistical analysis}

The results are presented as mean $\pm \mathrm{SD}$. The data were analyzed and compared with one-way ANOVA, followed by Newman-Keuls multiple comparison tests (PRISM GraphPad, version 5.0; GraphPad software Inc., San Diego, CA).

\section{RESULTS}

\section{Genotoxicity of the plant extract}

There was a significant decrease in the root MI in the roots treated with the extract at the time points $1 \mathrm{~h}, 2 \mathrm{~h}$, and $4 \mathrm{~h}$ in all concentrations used. The lowest dose of the extract used, that is, $0.2 \mathrm{mg} / \mathrm{ml}$ brought a significant decrease $(\mathrm{p}<0.05)$ in the MI at 2 and $4 \mathrm{~h}$ (Fig. 1). However, there was no significant effect on its $1 \mathrm{~h}$ treatment. The other concentrations such as $0.5 \mathrm{mg} / \mathrm{ml}, 1 \mathrm{mg} / \mathrm{ml}, 5 \mathrm{mg} / \mathrm{ml}$, and $10 \mathrm{mg} / \mathrm{ml}$ induced significant decrease in the MI in a time- and concentrationdependent manner (Fig. 1) The MI observed for water taken as normal 
control at 1,2 , and $4 \mathrm{~h}$ was $94.45 \pm 0.99,96.72 \pm 1.69$, and $96.56 \pm 1.09$, respectively, negative control $1 \%$ DMSO for 1,2 , and 4 h was $94.13 \pm 2.48$, $96.46 \pm 1.41$, and $97.57 \pm 0.57$, respectively, and the MI of the $0.2 \mathrm{mg} / \mathrm{ml}$ extract treated root tips was $92.05 \pm 2.57,83.62 \pm 3.26$, and $64.38 \pm 3.94$, respectively, for 1,2 , and $4 \mathrm{~h}$. Whereas, the $0.5 \mathrm{mg} / \mathrm{ml}$ had the MI of $83.13 \pm 3.51,64.45 \pm 4.49$, and $51.25 \pm 3.68$. The $1 \mathrm{mg} / \mathrm{ml}$ treatment displayed a MI of $74.00 \pm 3.09,46.33 \pm 2.74$, and $39.32 \pm 2.70$ for 1,2 , and $4 \mathrm{~h}$. The $5 \mathrm{mg} / \mathrm{ml}$ and the $10 \mathrm{mg} / \mathrm{ml}$ concentrations also followed a similar pattern as the previous lower doses displaying a significant decrease in the root MI in a time and dose-dependent manner, that is, $75.44 \pm 1.76,40.06 \pm 2.54,31.31 \pm 2.81$, and $73.56 \pm 0.45,29.52 \pm 5.52$, $14.34 \pm 1.82$, respectively, for 1,2 , and $4 \mathrm{~h}$.

The various cellular/chromosomal abnormalities such as chromosomal breaks, bridges, sticky metaphase, disturbed anaphase, multinucleated cells, and lesions, were counted for each treatment and expressed in percentage in Fig. 2 and Table 1. The relevant photographs are given in Fig. 3 and 4 shows images of the normal cell cycle stages.
Plant extract induced DNA damage, in situ lipid peroxidation and accumulated free radical

The genomic DNA damage analysis was carried out to examine the possible mechanism of the plant extract induced genotoxicity. The isolated DNA from the negative control (1\% DMSO), positive control $\left(3 \% \mathrm{H}_{2} \mathrm{O}_{2}\right)$, and $0.2,0.5,1,5$, and $10 \mathrm{mg} / \mathrm{ml}$ treated root samples for $1 \mathrm{~h}$ and $4 \mathrm{~h}$ were subjected to electrophoretic separation (Fig. 5). An evident DNA damage was seen in the $4 \mathrm{~h}$ treated roots at $5 \mathrm{mg} / \mathrm{ml}$ and $10 \mathrm{mg} / \mathrm{ml}$, whereas only a slight DNA damage was seen in the roots treated with $10 \mathrm{mg} / \mathrm{ml}$ extract for $1 \mathrm{~h}$.

The in situ histochemical localization of the lipid peroxides was observed by the Schiff's staining of the treated roots. Roots treated for $4 \mathrm{~h}$ for all extract concentrations developed a prominent pink color whereas roots treated for $1 \mathrm{~h}$ showed relatively less color (Fig. 6). The accumulation of reactive oxygen species in the extract treated roots was visualized by NBT staining. A characteristic blue color was observed in the $4 \mathrm{~h}$ treatment which increased with the increase in the dosage of treatment (Fig. 7).

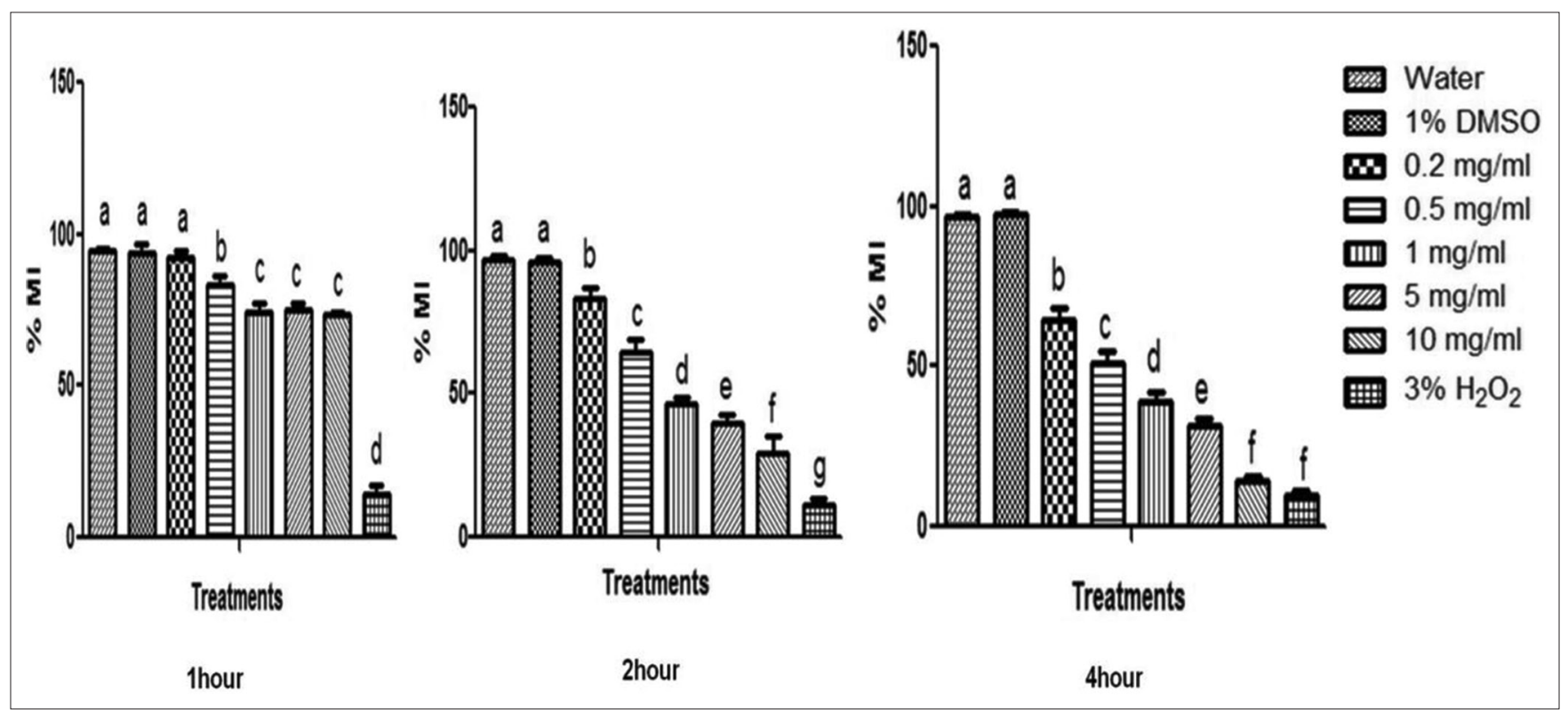

Fig. 1: The percentage mitotic index of various treatment groups, that is, $1 \%$ DMSO negative control, $3 \% \mathrm{H}_{2} \mathrm{O}_{2}$ positive control and different concentrations of the Lagenandra toxicaria extract for $1 \mathrm{~h}, \mathbf{2} \mathrm{h}$, and $4 \mathrm{~h}$ are shown in the bar graph. Bars with different superscript letters $a, b, c, d, e, f$, and $g$ indicate significant difference $(p<0.05)$ across the treatments

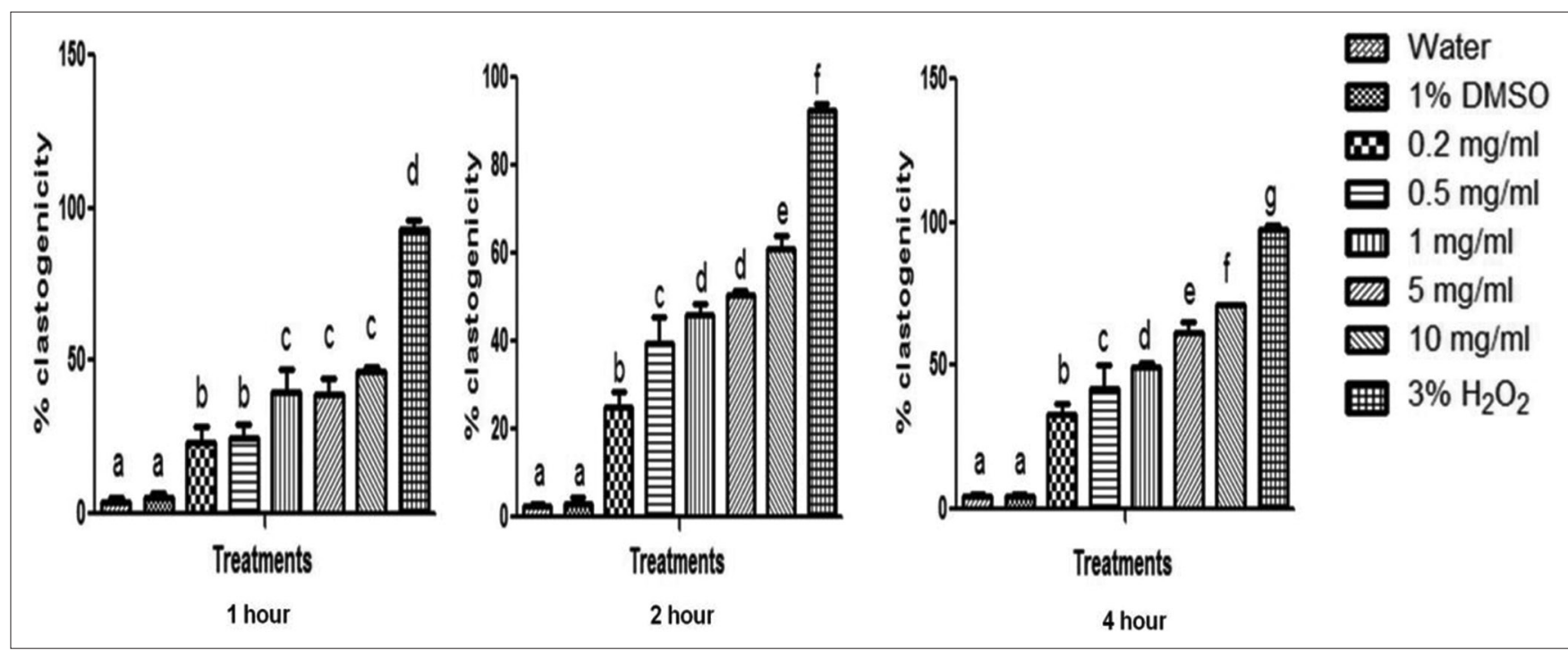

Fig. 2: The percentage clastogenicity in different control and extract treatments for $1 \mathrm{~h}, 2 \mathrm{~h}$, and $4 \mathrm{~h}$. Bars with different superscript letters $a, b, c, d, e, f$, and $g$ indicate significant difference $(p<0.05)$ across the treatments 
Polyphenol and flavonoid estimation

The L. toxicaria methanol extract had $64.89 \pm 1.81 \mathrm{mg}$ GAE/g of polyphenol content and 39.09 $\pm 1.98 \mathrm{mg} \mathrm{QE} / \mathrm{g}$ flavonoid.

\section{SEM analysis}

Root surface ultrastructure after the $4 \mathrm{~h}$ treatment with the extract and the control 1\% DMSO was observed under scanning electron microscope. The SEM images revealed a high degree of alterations in the surface morphology at the higher doses, root surface tissue shows fissures and cells were crumbled ( $5 \mathrm{mg} / \mathrm{ml}$ and $10 \mathrm{mg} / \mathrm{ml}$ ) in comparison with the control (20 $\mu \mathrm{M}$ and $10 \mu \mathrm{M}$ scale) (Fig. 8).

Table 1: Percentage clastogenicity in various treatments

\begin{tabular}{|c|c|c|c|}
\hline Treatment & $\begin{array}{l}\text { Time } \\
\text { (h) }\end{array}$ & $\begin{array}{l}\text { Total cells } \\
\text { Mean } \pm S D \\
(n=6)\end{array}$ & $\begin{array}{l}\% \text { Clastogenicity } \\
\text { Mean } \pm \text { SD } \\
(n=6)\end{array}$ \\
\hline \multirow[t]{3}{*}{ Water control } & 1 & $190.67 \pm 6.43$ & $4.18 \pm 1.35$ \\
\hline & 2 & $201 \pm 7.549$ & $2.82 \pm 0.32$ \\
\hline & 4 & $189.33 \pm 8.50$ & $4.40 \pm 1.12$ \\
\hline \multirow{3}{*}{$\begin{array}{l}\text { Negative control } \\
\text { (1\% DMSO) }\end{array}$} & 1 & $196 \pm 23.39$ & $5.01 \pm 1.54$ \\
\hline & 2 & $220 \pm 26.29$ & $3.32 \pm 1.40$ \\
\hline & 4 & $178 \pm 17.44$ & $4.85 \pm 0.56$ \\
\hline \multirow[t]{3}{*}{$0.2 \mathrm{mg} / \mathrm{ml}$} & 1 & $190 \pm 11.53$ & $23.67 \pm 4.86$ \\
\hline & 2 & $216 \pm 18.36$ & $24.91 \pm 3.43$ \\
\hline & 4 & $209 \pm 23.58$ & $33 \pm 4.17$ \\
\hline \multirow[t]{3}{*}{$0.5 \mathrm{mg} / \mathrm{ml}$} & 1 & $184 \pm 18.52$ & $25.11 \pm 4.41$ \\
\hline & 2 & $214 \pm 13.89$ & $39.72 \pm 5.69$ \\
\hline & 4 & $180 \pm 16.82$ & $41.99 \pm 8.33$ \\
\hline \multirow[t]{3}{*}{$1 \mathrm{mg} / \mathrm{ml}$} & 1 & $192 \pm 30$ & $39.64 \pm 7.95$ \\
\hline & 2 & $208 \pm 17.44$ & $46.27 \pm 2.15$ \\
\hline & 4 & $199 \pm 12.17$ & $49.3 \pm 1.78$ \\
\hline \multirow[t]{3}{*}{$5 \mathrm{mg} / \mathrm{ml}$} & 1 & $207 \pm 19$ & $38.75 \pm 5.38$ \\
\hline & 2 & $233 \pm 26.06$ & $50.38 \pm 1.05$ \\
\hline & 4 & $220 \pm 13.08$ & $61.67 \pm 3.98$ \\
\hline \multirow[t]{3}{*}{$10 \mathrm{mg} / \mathrm{ml}$} & 1 & $191 \pm 9.17$ & $46.28 \pm 1.75$ \\
\hline & 2 & $208 \pm 13.11$ & $61.31 \pm 2.53$ \\
\hline & 4 & $206 \pm 12.77$ & $71.01 \pm 0.73$ \\
\hline \multirow{3}{*}{ Positive control $\left(3 \% \mathrm{H}_{2} \mathrm{O}_{2}\right)$} & 1 & $180 \pm 17.44$ & $93.35 \pm 2.45$ \\
\hline & 2 & $213 \pm 6.08$ & $92.77 \pm 1.54$ \\
\hline & 4 & $178 \pm 19.08$ & $97.89 \pm 0.88$ \\
\hline
\end{tabular}

TTC cell viability test

The cell viability of the plant extract treated samples was checked and compared with the controls (normal control: water, negative control: $1 \%$ DMSO, and positive control: $3 \% \mathrm{H}_{2} \mathrm{O}_{2}$ ). The $1 \mathrm{~h}$ and $2 \mathrm{~h}$ of treatment of the root tip with different concentrations of the extract showed no effect on the cell viability and were all stained pink as in the negative control (Fig. 9). But the $10 \mathrm{mg} / \mathrm{ml}$ treatment for $4 \mathrm{~h}$ resulted in a moderate loss of cell viability showing less staining in comparison with the negative control (Fig. 9).

\section{FTIR analysis}

Both the extract treated and control samples were subjected FTIR spectroscopy to examine the possible changes in the biochemical components of the roots. The obtained spectral peaks were assigned to their characteristic organic molecules and the changes in the peak positions due to the chemical shift were noted. The peaks at the $1033 \mathrm{~cm}^{-1}$ and $1244 \mathrm{~cm}^{-1}$ were due to symmetric and asymmetric stretching of $\mathrm{P}=0$. The $1545 \mathrm{~cm}^{-1}$ and $1633 \mathrm{~cm}^{-1}$ positioned peaks were because of the amide II and amide I of the beta sheets and alpha helix of the secondary structure of proteins, respectively. $1735 \mathrm{~cm}^{-1}$ placed peak is due to ester $\mathrm{C}=0$ stretching. $2926 \mathrm{~cm}^{-1}$ placed peak is due to the $\mathrm{C}-\mathrm{H}$ asymmetric stretch of the methyl group of lipids and a broad peak at $3302 \mathrm{~cm}^{-1}$ was assigned to the $\mathrm{N}-\mathrm{H}$ stretching of proteins (Fig. 10).

\section{The antigenotoxicity potential of the plant extract}

The L. toxicaria plant extract showed a potential antigenotoxic activity. Genotoxicity was induced using $3 \% \mathrm{H}_{2} \mathrm{O}_{2}$ in the root tips. Roots treated with $3 \% \mathrm{H}_{2} \mathrm{O}_{2}$ for $1 \mathrm{~h}$ showed a higher clastogenecity of $93.45 \pm 2.33$, whereas the control roots (water and 1\% DMSO) showed only $4.66 \pm 1.48$ and $5.07 \pm 1.78$ clastogenicity, respectively. The post-treatment of the $3 \% \mathrm{H}_{2} \mathrm{O}_{2}$ treated roots with the $0.01 \mathrm{mg} / \mathrm{ml}$ and $0.02 \mathrm{mg} / \mathrm{ml}$ plant extract for $24 \mathrm{~h}$ significantly decreased the clastogenic effects of the $\mathrm{H}_{2} \mathrm{O}_{2}$ treatment. The $0.005 \mathrm{mg} / \mathrm{ml}, 0.01 \mathrm{mg} /$ $\mathrm{ml}$, and $0.02 \mathrm{mg} / \mathrm{ml}$ treatments showed a decreased clastogenicity with increased percentage of inhibition in a dose-dependent manner, that is, $10.73 \pm 6.66,43.31 \pm 13.56$, and $63.28 \pm 7.77$, respectively. The post-treatment of $0.0025 \mathrm{mg} / \mathrm{ml}$ extract did not show any evident percentage inhibition and the higher concentration of $0.04 \mathrm{mg} / \mathrm{ml}$ treatment for $24 \mathrm{~h}$ resulted in the total disruption of the root tip cells and hence they could not be counted (Fig. 11 and Table 2). The 3\% $\mathrm{H}_{2} \mathrm{O}_{2}$ induced cellular abnormalities were observed to be restored
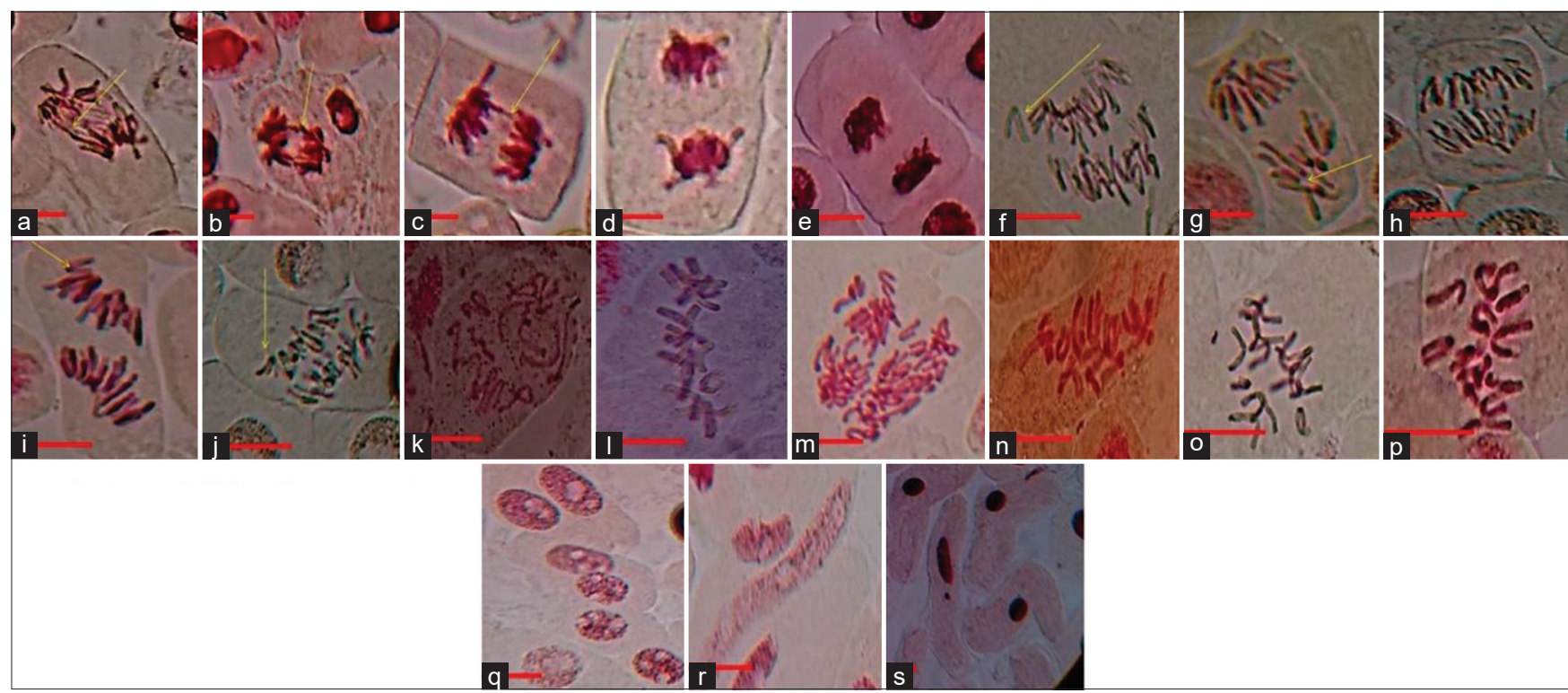

Fig. 3: Chromosomal aberrations and cellular clastogenicity after the experimental treatments $(\times 400$ magnification). Scale $20 \mu \mathrm{m}$. (a-c) Bridged anaphase, (d and e) Disturbed telophase, ( $\mathrm{f}-\mathrm{j}$ ) Loss of chromosome in anaphase, (k-p) Distorted metaphase, (q) Nuclear lesions, ( $r$ and s) Giant cell with strap nuclei 
after the treatment with the plant extract at 0.01 and $0.02 \mathrm{mg} / \mathrm{ml}$ (Fig. 12). Lipid peroxidation test was done using Schiff's reagent and it showed a pink color in 3\% hydrogen peroxide-treated roots, whereas the color intensity decreased in $0.01 \mathrm{mg} / \mathrm{ml}$ and $0.02 \mathrm{mg} /$ $\mathrm{ml}$ post-treated roots indicating the decreased lipid peroxidation. But the $0.04 \mathrm{mg} / \mathrm{ml}$ post-treatment resulted in the enhanced pink color indicating that at the higher concentrations the extract itself acts like a pro-oxidant (Fig. 13)

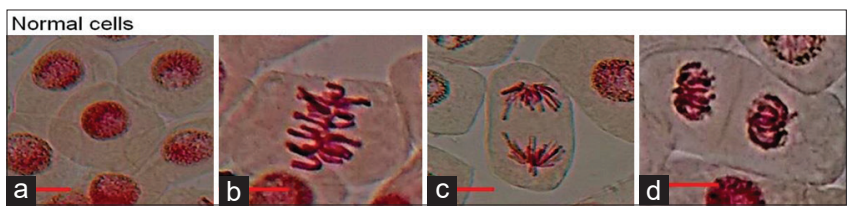

Fig. 4: Microscopic images of the normal cell cycle stages (a) Prophase, (b) Metaphase, (c) Anaphase, (d) Telophase $(\times 400$ magnification). Scale $20 \mu \mathrm{m}$

\section{DISCUSSION}

Genotoxic studies are now widely used for the evaluation of harmful effects of environmental pollutants and synthetic drugs [13,28-30]. In traditional herbal system, there is no systematic assessment of the possible harmful effects of the herbal formulations. Plants with genome modifying capabilities can be potential drug candidates particularly to disease like cancer. A. сера bioassay is a well-established model for genotoxic studies. The large-sized cells which are mitotically active with monocentric chromosomes that stain well with aceto-orcien make them suitable for such studies. Furthermore, the mutagenic responses across plants, mammals and humans are similar and hence the results obtained in this model can be extrapolated to higher organisms [8].

\section{Genotoxicity assay}

A genotoxic compound can alter the DNA of an organism thereby changing the structure and function of its chromosome. Such compounds disturb the cell cycle affecting their MI. MI is an accepted measure of cytotoxicity. A decrease in the MI below $50 \%$ becomes

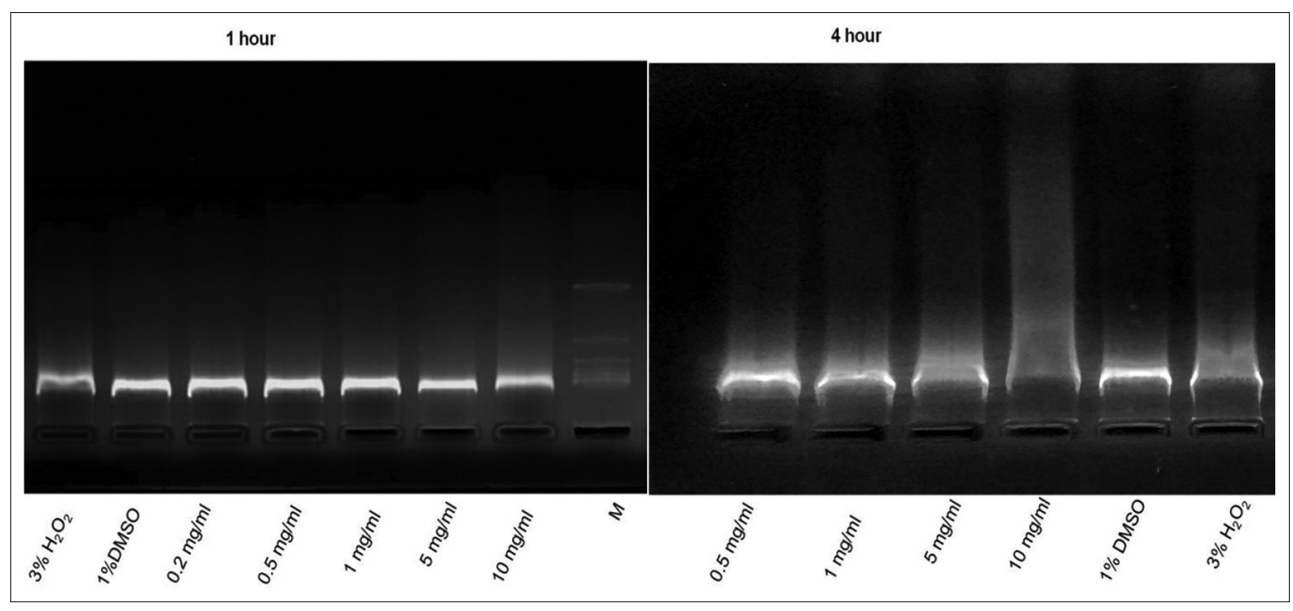

Fig. 5: DNA integrity study with various treatments

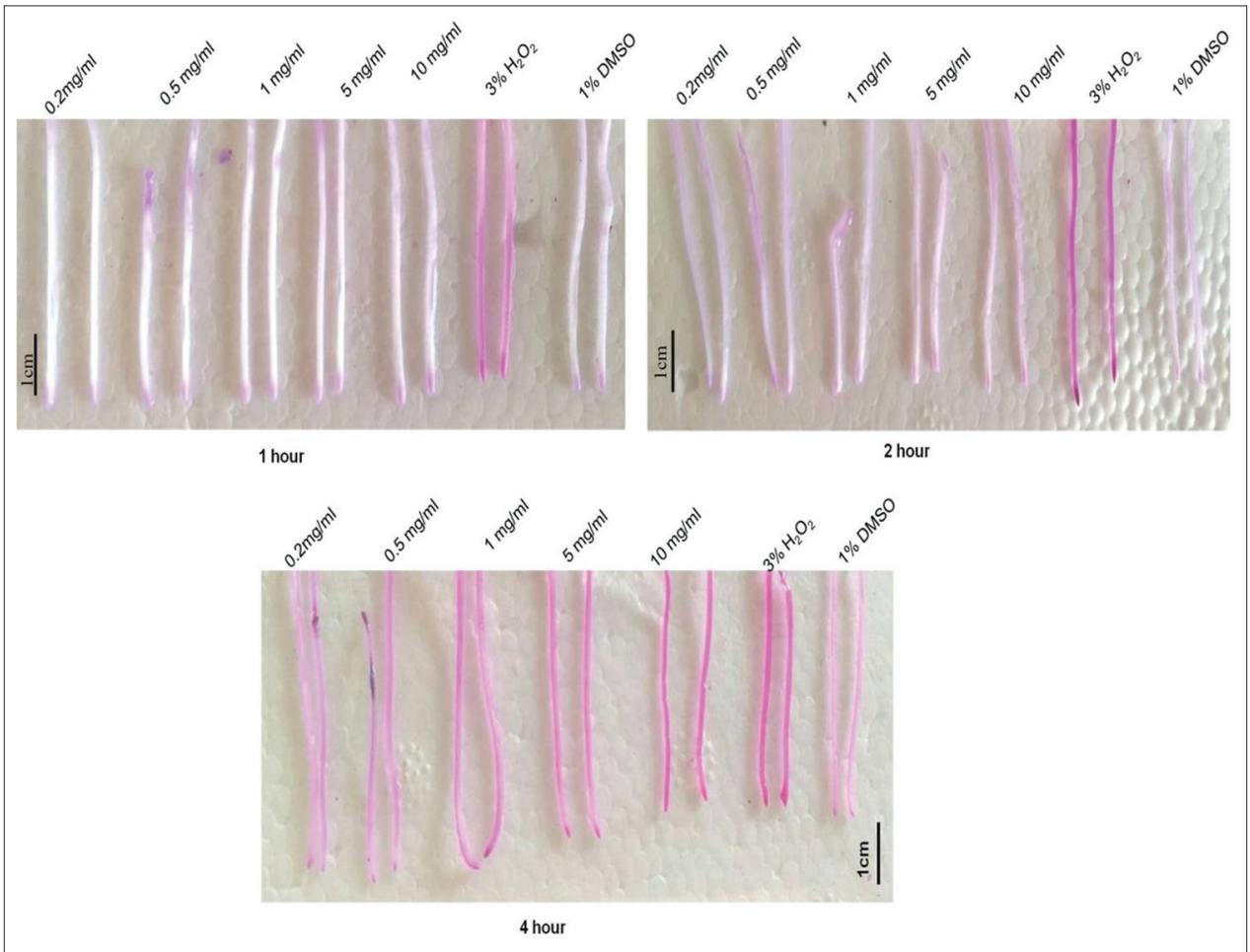

Fig. 6: Malondialdehyde detection assay 


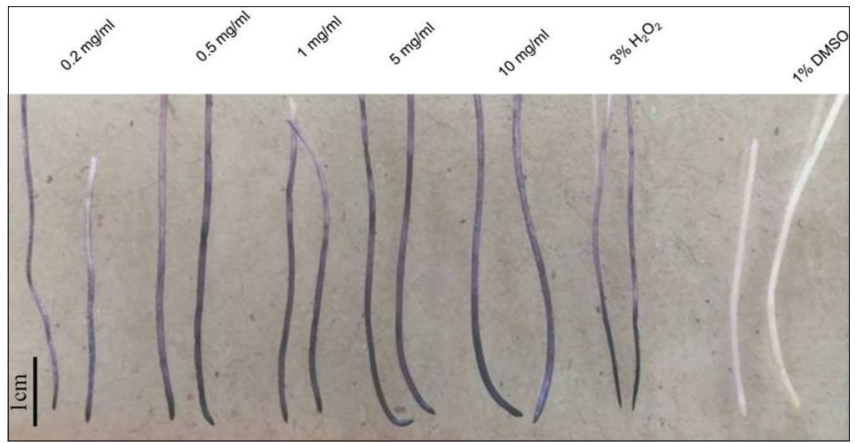

Fig. 7: Free radical detection assay in different treatments for $4 \mathrm{~h}$ sublethal for the organism where as a decrease below $22 \%$ cause lethal effect on the test organism [12,31]. In this study, the MI of the roots decreased significantly in all concentrations of the extract except for the lowest dose at the lower incubation period $(0.2 \mathrm{mg} / \mathrm{ml}$ for $1 \mathrm{~h})$. At $10 \mathrm{mg} / \mathrm{ml}$ of the plant extract, the MI was comparable to the decreased MI caused by $\mathrm{H}_{2} \mathrm{O}_{2}$. Decrease in MI suggests the anti-proliferative activities of the plant extract. This could be due to DNA replication failure at the $S$ phase or the cell cycle arrest at the G2 phase or reduction in the synthesis of ATP and nucleoproteins preventing the cell from proceeding to the mitosis $[32,33]$. The chromosomal aberrations such as sticky metaphase, chromosomal bridges, clumped chromosome, multipolar anaphase, and nuclear lesions were also increased in a time- and dose-dependent manner (Table 1 and Fig. 3). According to Rajeshwari et al. (2015) [25], such chromosomal aberrations are

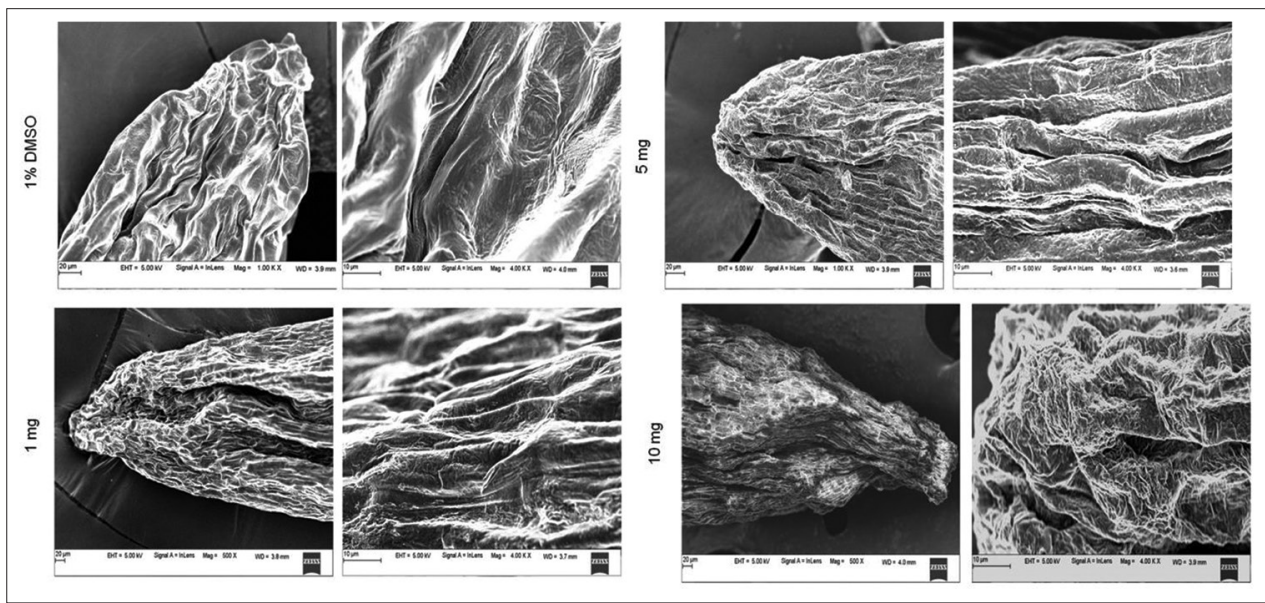

Fig. 8: Field emission scanning electron microscopy of the treated roots

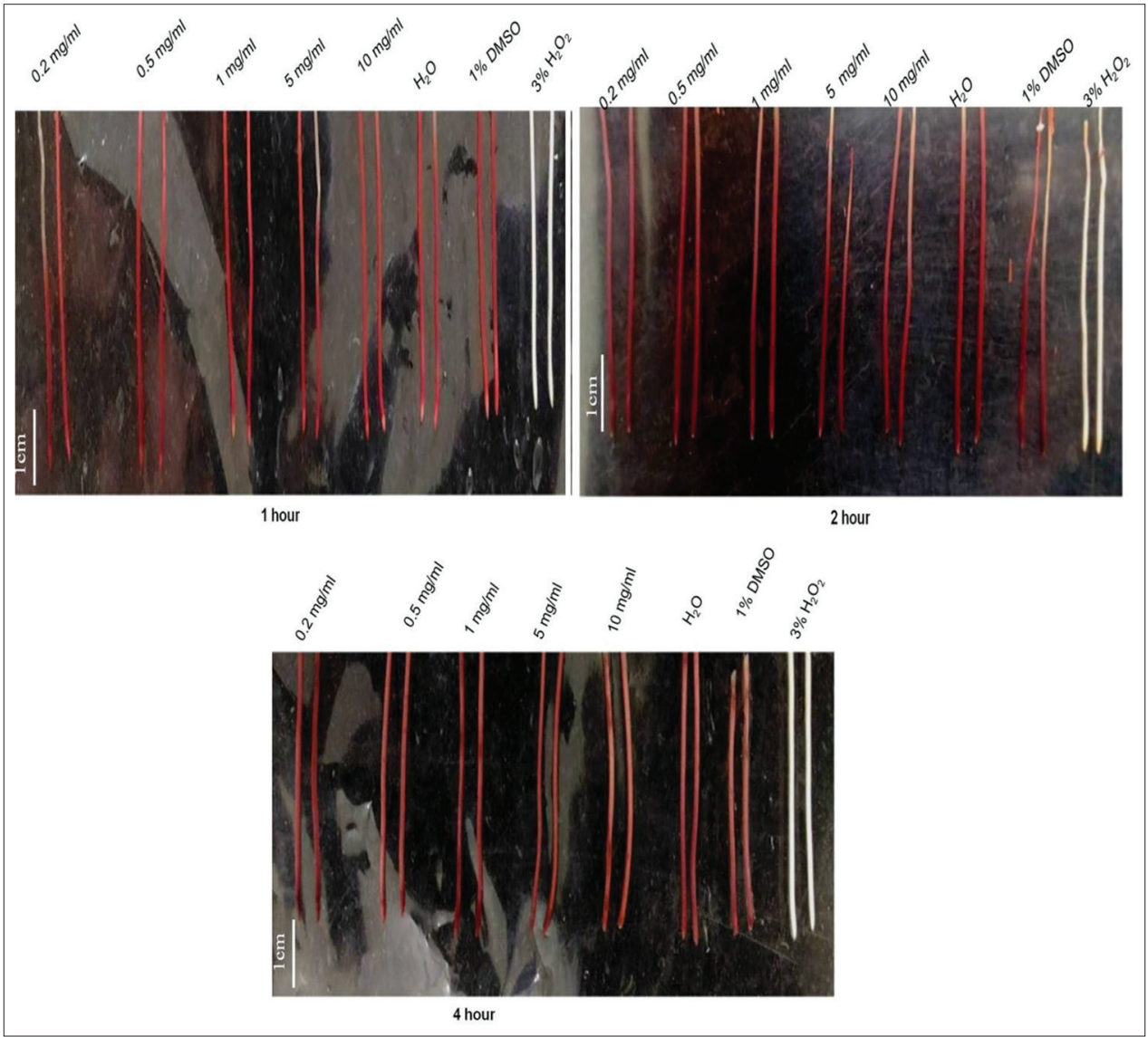

Fig. 9: Cell viability assay by triphenyl tetrazolium chloride 


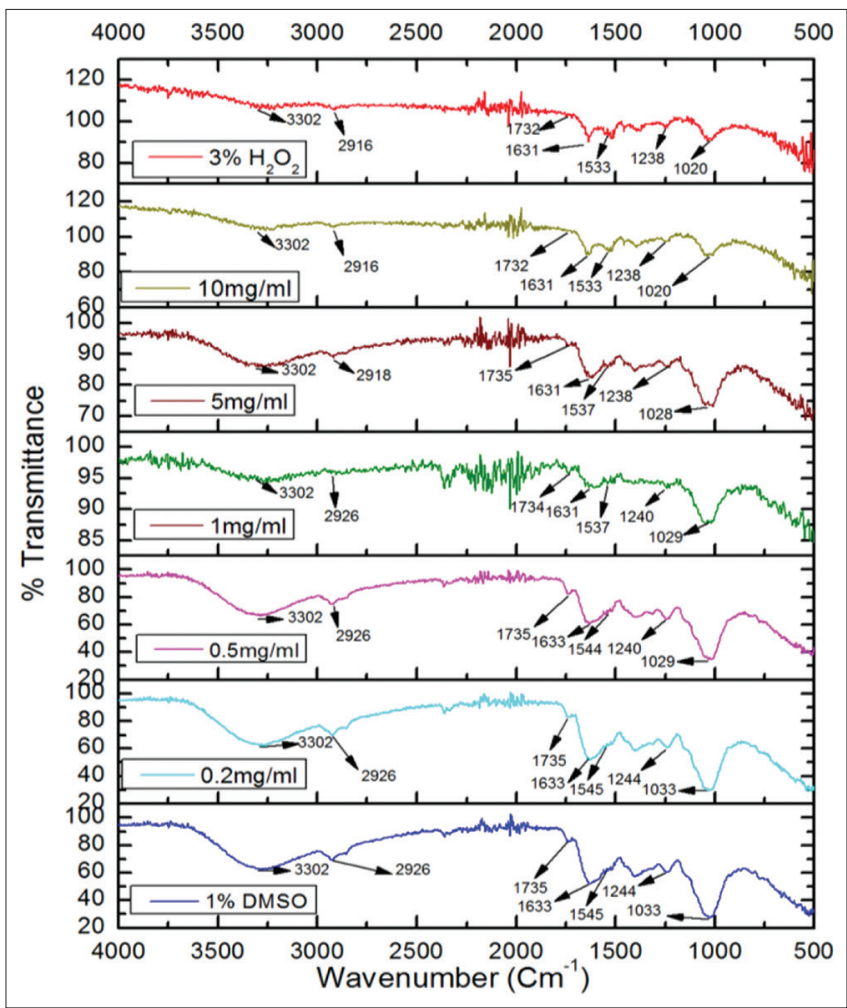

Fig. 10: Fourier-transform infrared spectroscopy analysis of treated roots

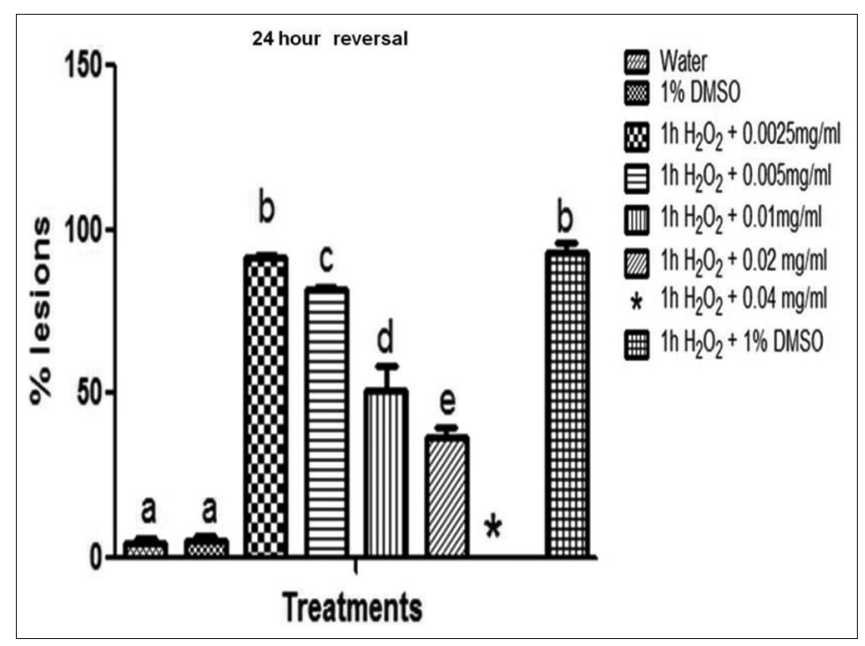

Fig. 11: Anti-genotoxic potential of the Lagenandra toxicaria extract: Graph represents the percentage lesions in the root tips treated with $3 \% \mathrm{H}_{2} \mathrm{O}_{2}$ and the percentage lesions after the $24 \mathrm{~h}$ modulatory treatment with plant extract. Column with different superscript letters (a, b, c, d, and e) are significantly different $(p<0.05)$

due to the depolymerization of spindle fibers resulting in shifting of poles. A toxicity of an irreversible type can cause these chromosomal stickiness and the formation of chromatin bridges are usually the product of an unequal chromatin exchange during the translocation processes leading to a structural chromosomal aberration [12,34]. Studies suggest that compounds such as flavonoids, polyphenols, alkaloids, and tannins when present in abundance act as pro-oxidants and damage the DNA and hinder the cell proliferation mechanism and also autoxidation of polyphenols will trigger oxidative stress and

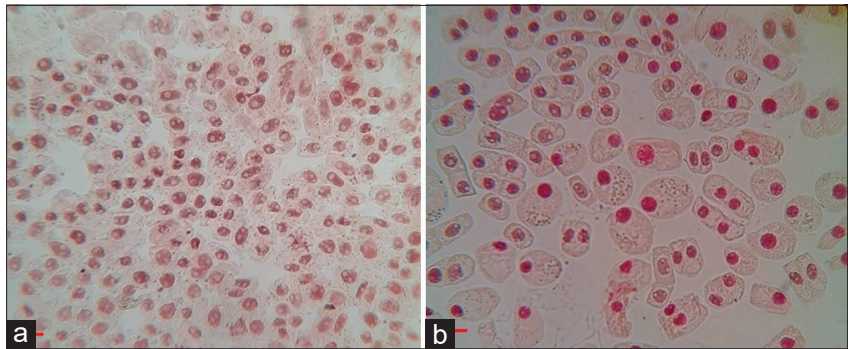

Fig. 12: Clastogenicity in the treated cells. (a) $3 \% \mathrm{H}_{2} \mathrm{O}_{2}$ for $1 \mathrm{~h}$ (b) Modulatory treatment with the extract for $24 \mathrm{~h}(0.02 \mathrm{mg} / \mathrm{ml})$. Scale $20 \mu \mathrm{m}$

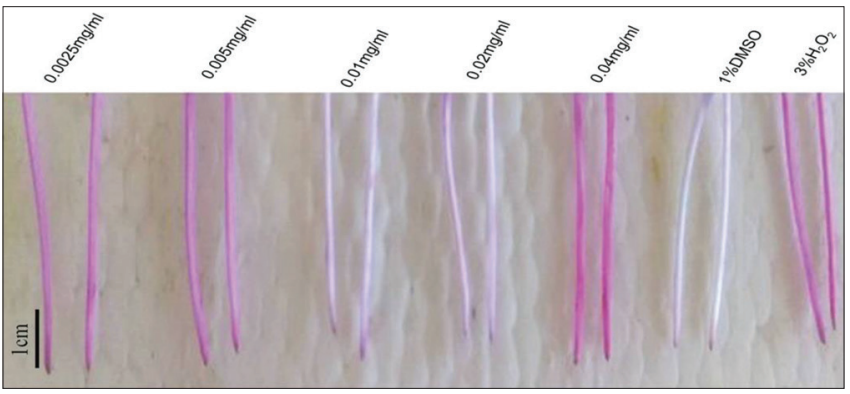

Fig. 13: Level of lipid peroxidation in roots treated with different lower concentration of the extract

free-radical generation depending on different conditions [35]. Such oxidative stress can also cause lipid peroxidation, leading to tissue damage. The lipid peroxidation can alter the cell membrane dynamics causing cell injury both in plants and animals. Lipid peroxidation in both plants and animals generates a small molecular weight compound known as the malondialdehyde (MDA) [36,37]. These aldehyde moieties on the cell surface can be detected by the Schiff's reagent [38]. Hence, in situ histochemical localization of the MDA was carried out in the roots treated with the plant extracts for different time intervals. The test revealed that the $4 \mathrm{~h}$ treatment of the plant extracts induced high degree of lipid peroxidation in a dose-dependent manner.

The extract also affects the DNA integrity at higher doses. The study showed a maximum loss of DNA integrity at $10 \mathrm{mg} / \mathrm{ml}$ treatment for $4 \mathrm{~h}$. The increased DNA damage and lipid peroxidation is attributed to the free-radical generation due to the presence of higher concentration of plant polyphenols, flavonoids, tannin, etc. [39,40]. In agreement with the previous studies $[23,24]$, the NBT free-radical assay also suggested the free-radical generation in a dose-dependent manner (Fig. 7). SEM analysis of the roots treated with higher doses of extract for longer duration showed characteristic morphological difference in comparison to the control groups (Fig. 8). Each type of chemical bond in a cellular macromolecule exhibits its own vibrational properties. Under the influence of oxidative stress, these characteristic vibrational modes of a biomolecule get altered [13]. Here, the samples (both treated and controls) were subjected to FTIR studies. The various peaks obtained for different macromolecules were observed at same wave numbers as in earlier studies (Fig. 10) [13,25]. The peak appeared at the $1633 \mathrm{~cm}^{-1}$ in control samples represents the $\alpha$-helices and $\beta$ sheets that constitutes the secondary structures of the proteins. This peak was shifted slightly to $1631 \mathrm{~cm}^{-1}$ among the treated groups. This chemical shift suggests the altered $\alpha$-helices and $\beta$ sheets among the treated samples and also shifting of peaks in treated groups compared with the control group at $1033 \mathrm{~cm}^{-1}$ and $1244 \mathrm{~cm}^{-1}$ indicate damage in the phosphate backbone (Fig. 10).

Antigenotoxic/genoprotective effects of $L$. toxicaria

At higher doses, the plant extracts induce genotoxicity but it is also a well-established fact that these same compounds at a 
Table 2: Percentage of the nuclear lesions in antigenotoxicity study

\begin{tabular}{llll}
\hline Treatment & $\begin{array}{l}\text { Total cells } \\
\text { Mean } \pm \mathbf{S D}(\mathbf{n}=\mathbf{6})\end{array}$ & $\begin{array}{l}\text { Total number of } \\
\text { nuclear lesions } \\
\text { Mean } \pm \mathbf{S D}(\mathbf{n}=\mathbf{6})\end{array}$ & $\begin{array}{l}\text { Percentage of } \\
\text { nuclear lesions } \\
\mathbf{M e a n} \pm \mathbf{S D}(\mathbf{n}=\mathbf{6})\end{array}$ \\
\hline Water control & $192.33 \pm 3.51$ & $9 \pm 3$ & $4.66 \pm 1.48$ \\
Negative control(1\% DMSO) & $203 \pm 5.29$ & $10 \pm 3.79$ & $5.07 \pm 1.78$ \\
$3 \% \mathrm{H}_{2} \mathrm{O}_{2}+1 \% \mathrm{DMSO}$ & $200 \pm 15.62$ & $187 \pm 10.01$ & $93.45 \pm 2.33$ \\
$3 \% \mathrm{H}_{2} \mathrm{O}_{2}+0.0025 \mathrm{mg} / \mathrm{ml}$ & $202 \pm 13.08$ & $184 \pm 10.69$ & $91.28 \pm 0.73$ \\
$3 \% \mathrm{H}_{2} \mathrm{O}_{2}+0.005 \mathrm{mg} / \mathrm{ml}$ & $218 \pm 29.05$ & $180 \pm 25.01$ & $82.09 \pm 0.69$ \\
$3 \% \mathrm{H}_{2} \mathrm{O}_{2}+0.01 \mathrm{mg} / \mathrm{ml}$ & $215 \pm 13.89$ & $110 \pm 24.01$ & $50.99 \pm 7.59$ \\
$3 \% \mathrm{H}_{2} \mathrm{O}_{2}+0.02 \mathrm{mg} / \mathrm{ml}$ & $201 \pm 23.64$ & $75 \pm 13.75$ & $37.13 \pm 2.66$ \\
\hline
\end{tabular}

Column with different superscript letters is significantly different $(\mathrm{p}<0.05)$

lower concentration act as an anti-genotoxic agent protecting the DNA from oxidative damage and keep the cell intact. These two contradictory outcomes are the results of difference in the compound concentration $[41,42]$. In this study, the lower doses of $0.01 \mathrm{mg} / \mathrm{ml}$ and $0.02 \mathrm{mg} / \mathrm{ml}$ did show antigenotoxic potential showing lesser or cleared nuclear lesions that were induced by $\mathrm{H}_{2} \mathrm{O}_{2}$ treatment (Fig. 12). This can be attributed to the chemoprotective activity of the lower dose of the extract. The treatment showed a significant reduction in percentage nuclear lesions from $93.45 \pm 2.33$ to $37.13 \pm 2.66$ (Table 2). The compounds with such bimodal activities having genotoxic effect at higher doses and genoprotective properties at the lower doses are referred to as Janus-faced compounds [13]. The crude extracts are complex mixtures of phytochemicals which work synergistically either as a genoprotective or genotoxic substance. At lower concentration polyphenols, flavonoids, tannins, and alkaloids show antigenotoxic property $[12,13,43]$. The observed decrease in the $\mathrm{H}_{2} \mathrm{O}_{2}$ induced genotoxicity after the extract modulatory treatment is because these compounds act as antioxidants at the lower concentration in the extract. A study on Escherichia coli has found that the polyphenols such as the vanillin, cinnamaldehyde, coumarin, and tannic acid are involved in the regulation of DNA replication and repair systems after the free-radical attack. Another possible explanation for the action of extract is that it can induce the expression of the DNA repair related gene such as the DNA glycosylases which can alkylate the DNA bases and activate the DNA repair systems $[12,44]$.

\section{CONCLUSION}

The study showed that the L. toxicaria rhizome methanol extract possesses both genotoxic and anti-genotoxic properties. The extract induces genotoxicity at higher doses at higher time intervals which were confirmed by the decreased MI, increased ROS generation, DNA damage, and lipid peroxidation. The total polyphenol estimation revealed that the extract does contain polyphenols and these polyphenols trigger oxidative stress and cell death by undergoing autoxidation.

Further, we explored the antigenotoxic property of the plant extract and showed that, at lower concentration the extract protects the $A$. cepa cells against $3 \% \mathrm{H}_{2} \mathrm{O}_{2}$ induced genotoxicity. The study presents preliminary data on the potential of the L. toxicaria plant extract as genotoxic and a promising genoprotective agent at lower doses. Further studies are required to unravel the molecular mechanisms that underlie these observed phenomenons.

\section{ACKNOWLEDGMENT}

This work was supported by Directorate of minorities Karnataka Ph.D fellowship (DOM/FELLOWSHIP/CR-2/2017-18).

I thank full to Mangalore university DST-PURSE and USIC.

\section{AUTHORS CONTRIBUTION}

The first author carried out the experiments, analysis, and preparation of the manuscript. The second author assisted in the planning and investigation of the experiment and final evaluation of the manuscript.

\section{CONFLICTS OF INTEREST}

Authors declare there are no conflicts of interests.

\section{AUTHOR'S FUNDING}

Directorate of minorities Karnataka Ph.D fellowship (DOM/ FELLOWSHIP/CR-2/2017-18).

\section{REFERENCES}

1. Parasuraman S, Thing GS, Dhanaraj SA. Polyherbal formulation: Concept of ayurveda. Pharmacogn Rev 2014;8:73-80.

2. Selvakumari PA. Pharmacognostical standardisation of Lagenandra toxicaria Dalz. Malaysian J Sci 2014;33:163-75.

3. Van ED, Goossens K, Smeets K, Van FL, Verhaert P, Peumans WJ. The major tuber storage protein of Araceae species is a lectin. Characterization and molecular cloning of the lectin from Arum maculatum L. Plant Physiol 1995;107:1147-58.

4. De Mejia EG, Prisecaru VI. Lectins as bioactive plant proteins: A potential in cancer treatment. Crit Rev Food Sci Nutr 2005;45:425-45.

5. Kurdekar RR, Hegde GR, Hegde G, Hebbar SS. Antimicrobial screening of medicinal plants against human pathogens- A comparative account of two different methods of extraction. Int J Drug Dev Res 2012;4:82-9

6. Sivarajan VV, Balachandran I. Ayurvedic Drugs and their Plant Sources. New Delhi: Oxford and IBH Publishing Company Private Ltd.; 1994. p. 374-6.

7. Bonciu E, Firbas P, Fontanetti CS, Wusheng J, Karaismailoğlu MC, Liu D, et al. An evaluation for the standardization of the Allium cepa test as cytotoxicity and genotoxicity assay. Caryologia 2018;71:191-209.

8. Fiskesjö G. The Allium test--an alternative in environmental studies: The relative toxicity of metal ions. Mutat Res 1998;197:243-60.

9. Finkel T, Holbrook NJ. Oxidants, oxidative stress and the biology of ageing. Nature 2000;408:239-47.

10. Reuter S, Gupta SC, Chaturvedi MM, Aggarwal BB. Oxidative stress, inflammation, and cancer: How are they linked? Free Radic Biol Med 2010;49:1603-16.

11. Devi HP, Mazumder PB. Methanolic extract of Curcuma caesia Roxb. prevents the toxicity caused by cyclophosphamide to bone marrow cells, liver and kidney of mice. Pharmacogn Res 2016;8:43-9.

12. Prajitha V, Thoppil JE. Genotoxic and antigenotoxic potential of the aqueous leaf extracts of Amaranthus spinosus Linn. using Allium cepa assay. S Afr J Bot 2016;102:18-25.

13. Shetty A, Venkatesh T, Suresh PS, Tsutsumi R. Exploration of acute genotoxic effects and antigenotoxic potential of gambogic acid using Allium cepa assay. Plant Physiol Biochem 2017;118:643-52.

14. Rani G, Kaur K, Wadhwa R, Kaul SC, Nagpal A. Evaluation of the anti-genotoxicity of leaf extract of Ashwagandha. Food Chem Toxicol 2005;43:95-8

15. Yuet Ping K, Darah I, Yusuf UK, Yeng C, Sasidharan S. Genotoxicity of Euphorbia hirta: An Allium cepa assay. Molecules 2012;17:7782-91.

16. Ghosh I, Mukherjee A, Mukherjee A. In planta genotoxicity of nZVI: Influence of colloidal stability on uptake, DNA damage, oxidative stress and cell death. Mutagenesis 2017;32:371-87.

17. Ghosh M, Bandyopadhyay M, Mukherjee A. Genotoxicity of titanium dioxide (TiO2) nanoparticles at two trophic levels: Plant and human lymphocytes. Chemosphere 2010;81:1253-62.

18. Qin R, Wang C, Chen D, Björn LO, Li S. Copper-induced root growth inhibition of Allium cepa var. Agrogarum L. involves disturbances in cell division and DNA damage. Environ Toxicol Chem 2015;34:1045-55. 
19. Khanal S, Shakya N, Thapa K, Pant DR. Phytochemical investigation of crude methanol extracts of different species of Swertia from Nepal. BMC Res Notes 2015;8:821.

20. Figueirôa ED, Nascimento da Silva LC, de Melo CM, Neves JK, da Silva NH, PereiraVR, et al. Evaluation of antioxidant, immunomodulatory, and cytotoxic action of fractions from Eugenia uniflora L. and Eugenia malaccensis L.: Correlation with polyphenol and flavanoid content. ScientificWorldJournal 2013;2013:125027.

21. Chandel S, Kaur S, Singh HP, Batish DR, Kohli RK. Exposure to 2100 $\mathrm{MHz}$ electromagnetic field radiations induces reactive oxygen species generation in Allium cepa roots. J Microsc Ultrastruct 2017;5:225-9.

22. Shaymurat T, Gu J, Xu C, Yang Z, Zhao Q, Liu Y, et al. Phytotoxic and genotoxic effects of $\mathrm{ZnO}$ nanoparticles on garlic (Allium sativum $\mathrm{L}$.): A morphological study. Nanotoxicology 2012;6:241-8.

23. Mangalampalli B, Dumala N, Grover P, Allium cepa root tip assay in assessment of toxicity of magnesium oxide nanoparticles and microparticles. J Environ Sci 2018;66:125-37.

24. Soltys D, Rudzińska-Langwald A, Kurek W, Gniazdowska A, Sliwinska E, Bogatek R. Cyanamide mode of action during inhibition of onion (Allium cepa L.) root growth involves disturbances in cell division and cytoskeleton formation. Planta 2011;234:609-21.

25. Rajeshwari A, Kavitha S, Alex SA, Kumar D, Mukherjee A, Chandrasekaran $\mathrm{N}$, et al. Cytotoxicity of aluminum oxide nanoparticles on Allium cepa root tip--effects of oxidative stress generation and biouptake. Environ Sci Pollut Res 2015;22:11057-66.

26. Ahmed B, Dwivedi S, Abdin MZ, Azam A, Al-Shaeri M, Khan MS, et al. Mitochondrial and chromosomal damage induced by oxidative

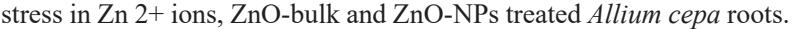
Sci Rep 2017;7:1-14.

27. Shahid M, Ahmed B, Zaidi A, Khan MS. Toxicity of fungicides to Pisum sativum: A study of oxidative damage, growth suppression, cellular death and morpho-anatomical changes. RSC Adv 2018;8:38483-98.

28. Kumari M, Mukherjee A, Chandrasekaran N. Genotoxicity of silver nanoparticles in Allium cepa. Sci Total Environ 2009;407:5243-6.

29. Leme DM, Marin-Morales MA. Chromosome aberration and micronucleus frequencies in Allium cepa cells exposed to petroleum polluted water--a case study. Mutat Res 2008;650:80-6.

30. Silveira GL, Lima MG, Reis GB, Palmieri MJ, Andrade-Vieria LF. Toxic effects of environmental pollutants: Comparative investigation using
Allium cepa L. and Lactuca sativa L. Chemosphere 2017;178:359-67.

31. Rosculete CA, Bonciu E, Rosculete E, Olaru LA. Determination of the environmental pollution potential of some herbicides by the assessment of cytotoxic and genotoxic effects on Allium cepa. Int $\mathrm{J}$ Environ Res Public Health 2018;16:75

32. Özkara A, Akyıl D, Eren Y, Erdoğmuş SF. Potential cytotoxic effect of Anilofos by using Allium cepa assay. Cytotechnology 2015;67:783-91

33. Sharma S, Sharma S, Vig AP. Antigenotoxic potential of plant leaf extracts of Parkinsonia aculeata L. using Allium cepa assay. Plant Physiol Biochem 2018;130:314-23.

34. Zhang H, Jiang Z, Qin R, Zhang H, Zou J, Jiang W, et al. Accumulation and cellular toxicity of aluminum in seedling of Pinus massoniana. BMC Plant Biol 2014;14:264.

35. Joubert E, Winterton P, Britz TJ, Gelderblom WC. Antioxidant and prooxidant activities of aqueous extracts and crude polyphenolic fractions of rooibos (Aspalathus linearis). J Agric Food Chem 2005;53:10260-7.

36. Gaweł S, Wardas M, Niedworok E, Wardas P. Malondialdehyde (MDA) as a lipid peroxidation marker. Wiad Lek 2004;57:453-5.

37. Jain R, Srivastava S, Solomon S, Shrivastava AK, Chandra A. Impact of excess zinc on growth parameters, cell division, nutrient accumulation, photosynthetic pigments and oxidative stress of sugarcane (Saccharum spp.). Acta Physiol Plant 2010;32:979-86.

38. Wu L, Yi H, Yi M. Assessment of arsenic toxicity using Allium/Vicia root tip micronucleus assays. J Hazard Mater 2009;176:952-6.

39. Azqueta A, Collins A. Polyphenols and DNA damage: A mixed blessing. Nutrients 2016;8:785.

40. Kaur G, Singh HP, Batish DR, Kohli RK. Pb-inhibited mitotic activity in onion roots involves DNA damage and disruption of oxidative metabolism. Ecotoxicology 2014;23:1292-304.

41. Cao J, Jiang LP, Liu Y, Yang G, Yao XF, Zhong LF. Curcumininduced genotoxicity and antigenotoxicity in HepG2 cells. Toxicon 2007;49:1219-22.

42. Choi EJ, Chee KM, Lee BH. Anti- and prooxidant effects of chronic quercetin administration in rats. Eur J Pharmacol 2003;482:281-5.

43. Mateus PG, Wolf VG, Borges MS, Ximenes VF. Quercetin: Prooxidant effect and apoptosis in cancer. Stud Nat Prod Chem 2018;58:265-88.

44. Ferguson LR. Role of plant polyphenols in genomic stability. Mutat Res 2001;475:89-111. 